\title{
Direct Targeting Options for STAT3 and STAT5 in Cancer
}

\author{
Anna Orlova ${ }^{1}{ }^{\circledR}$, Christina Wagner ${ }^{1}$, Elvin D. de Araujo ${ }^{2,3}$, Dávid Bajusz ${ }^{4}{ }^{(\mathbb{B}}$, \\ Heidi A. Neubauer ${ }^{1}$ D, Marco Herling ${ }^{5}$, Patrick T. Gunning 2,3, György M. Keserú 4 \\ and Richard Moriggl ${ }^{1, *}$ \\ 1 Institute of Animal Breeding and Genetics, University of Veterinary Medicine, 1210 Vienna, Austria; \\ anna.orlova@vetmeduni.ac.at (A.O.); Christina-Maria.Wagner@vetmeduni.ac.at (C.W.); \\ Heidi.Neubauer@vetmeduni.ac.at (H.A.N.) \\ 2 Department of Chemical and Physical Sciences, University of Toronto Mississauga, \\ Mississauga, ON L5L 1C6, Canada; e.dearaujo@mail.utoronto.ca (E.D.d.A.); \\ patrick.gunning@utoronto.ca (P.T.G.) \\ 3 Centre for Medicinal Chemistry, University of Toronto Mississauga, Mississauga, ON L5L 1C6, Canada \\ 4 Medicinal Chemistry Research Group, Research Centre for Natural Sciences, H-1117 Budapest, Hungary; \\ bajusz.david@ttk.mta.hu (D.B.); keseru.gyorgy@ttk.mta.hu (G.M.K.) \\ 5 Department I of Internal Medicine, Center for Integrated Oncology (CIO), Excellence Cluster for Cellular \\ Stress Response and Aging-Associated Diseases (CECAD), and Center for Molecular Medicine \\ Cologne (CMMC), Cologne University, 50937 Cologne, Germany; marco.herling@uk-koeln.de \\ * Correspondence: richard.moriggl@vetmeduni.ac.at
}

Received: 17 October 2019; Accepted: 29 November 2019; Published: 3 December 2019

\begin{abstract}
Signal transducer and activator of transcription (STAT)3 and STAT5 are important transcription factors that are able to mediate or even drive cancer progression through hyperactivation or gain-of-function mutations. Mutated STAT3 is mainly associated with large granular lymphocytic T-cell leukemia, whereas mutated STAT5B is associated with T-cell prolymphocytic leukemia, T-cell acute lymphoblastic leukemia and $\gamma \delta$ T-cell-derived lymphomas. Hyperactive STAT3 and STAT5 are also implicated in various hematopoietic and solid malignancies, such as chronic and acute myeloid leukemia, melanoma or prostate cancer. Classical understanding of STAT functions is linked to their phosphorylated parallel dimer conformation, in which they induce gene transcription. However, the functions of STAT proteins are not limited to their phosphorylated dimerization form. In this review, we discuss the functions and the roles of unphosphorylated STAT3/5 in the context of chromatin remodeling, as well as the impact of STAT5 oligomerization on differential gene expression in hematopoietic neoplasms. The central involvement of STAT3/5 in cancer has made these molecules attractive targets for small-molecule drug development, but currently there are no direct STAT3/5 inhibitors of clinical grade available. We summarize the development of inhibitors against the SH2 domains of STAT3/5 and discuss their applicability as cancer therapeutics.
\end{abstract}

Keywords: STAT3; STAT5; cancer; small-molecule inhibitors

\section{Introduction}

The Janus kinase/Signal transducer and activator of transcription (JAK-STAT) pathway is one of the core cancer pathways that integrates signals from cytokines, hormones and growth factors to induce or repress gene expression in cells [1]. The pathway consists of four JAK kinases (JAK1, JAK2, JAK3 and TYK2) and seven STAT transcription factors (STAT1, STAT2, STAT3, STAT4, STAT5A, STAT5B and STAT6). Despite conserved structure and a common mechanism of action, STAT family members show distinct and even opposite functions in tumor biology. 
STAT1 is generally not associated with promoting tumor growth and mostly mediates tumor-suppressive and pro-apoptotic functions [2,3]. Consistently, STAT1 ${ }^{-/-}$mice are more prone to tumor development and STAT1 deletion in leukemic cells decreases MHC class I expression [4,5]. Surprisingly, in a v-abl-driven model of STAT1 ${ }^{-/-}$leukemic cells initially harboring low MHC class I, enhanced MHC class I expression was gained during the disease progression, thereby reducing tumor recognition by NK cells [6]. As an exception, STAT1 was shown to be an oncogenic driver in T-cell acute lymphoblastic leukemia (T-ALL) and $\mathrm{ALK}^{+}$anaplastic large cell lymphoma (ALCL), and STAT1 is associated with the JAK2 exon 12 mutation in the progression of myeloproliferative neoplasms (MPNs) [7-9]. Reports on direct involvements of STAT2, STAT4 and STAT6 in cancerous processes are scarce and are not discussed here further [10]. Associations of STAT3 and STAT5 with cancer progression are well established and heavily studied, and hence, are the main focus of this review.

\section{Role of STAT3 and STAT5 in Cancer}

STAT3 and STAT5 proteins are of particular interest in cancer research, as their hyperactivation was reported in processes ranging from inflammation and autoimmunity to infection and cancer. Within the latter, these proteins have been implicated in tumor initiation, as well as in metastasis or in conferring drug resistance mechanisms [10-12]. Constitutive hyperactivation of STAT3 and STAT5, as a result of their gain-of-function mutations or via enhanced signaling from upstream drivers, promotes tumor cell growth and survival [3].

STAT3 is the best-studied family member of the JAK-STAT pathway in cancer, and is a known oncogene in various types of solid malignancies, like melanoma or lung cancer [13-15]. Furthermore, both STAT3 and STAT5 are reported to play a major role in the progression and pathogenesis of prostate cancer [16-18]. Hyperactivation of STAT3 and STAT5 is commonly associated with an upstream oncogenic driver, such as hyperactive mutated tyrosine kinases, for example, JAK2 $^{\mathrm{V} 617 \mathrm{~F}}$ or FLT3-ITD, or fusion proteins such as BCR-ABL, TEL-JAK2 or TEL-ABL1 [3,19-21]. The role of STAT5 in the transformation process induced by BCR-ABL p210 fusion protein has been particularly well-studied. It was shown that the absence of STAT5 diminishes the ability of cells to transform even upon harboring potent oncogenes such as BCR-ABL. Inducible deletion of STAT5 arrests and kills chronic myeloid leukemia (CML) cell lines, defining STAT5 as a therapeutic cancer target [22]. Hyperactivation of STAT3 and STAT5 can also occur via direct mutation in these genes, which is also associated with cancer progression in patients [1]. Interestingly, mutated STAT3 is mainly associated with large granular lymphocytic T-cell leukemia (T-LGLL), whereas mutated STAT5B is found in patients with T-cell prolymphocytic leukemia (T-PLL), T-ALL, $\gamma \delta$ T-cell-derived lymphoma and monomorphic epitheliotropic intestinal T-cell lymphoma (MEITL) [23-25].

Inhibitors of kinases upstream of STAT3/5 are available, but patients often relapse by developing drug resistance through persistent signaling or enhanced upregulation of STAT3 or STAT5 expression $[21,26]$. Targeting STAT3 and STAT5 directly or in combination with tyrosine kinase inhibitors might be an attractive way to overcome these resistance mechanisms [27].

\section{Non-Canonical Functions of STAT3 and STAT5}

STAT proteins share similar structural architecture including five domains: an N-terminal domain, a coiled-coil domain, a DNA-binding domain, an SH2 domain and a C-terminal transactivation domain [11] (Figure 1a). Upon phosphorylation, STAT5 undergoes a conformational change and forms parallel dimers via the SH2 domain (Figure 1b). This conformation allows the dimers to be recognized by importins and facilitates transport into the nucleus, where they bind GAS consensus sequences to induce target gene transcription. Such dramatic conformational rearrangements are possible due to the flexible linkers that are connecting the core fragment of STAT5 with its N- and C-terminus [28-30]. The complex approach of molecular dynamic simulations and bioinformatic analyses identified three distinct interaction surfaces within the dimer unique to STAT5, which include intramolecular interactions between the $\mathrm{SH} 2$ domain and the phosphotyrosine motif $[28,31]$. 
a

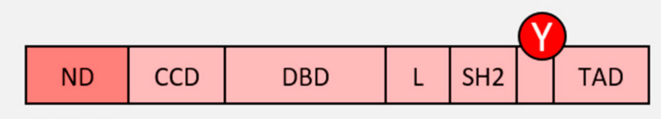

STAT5

C

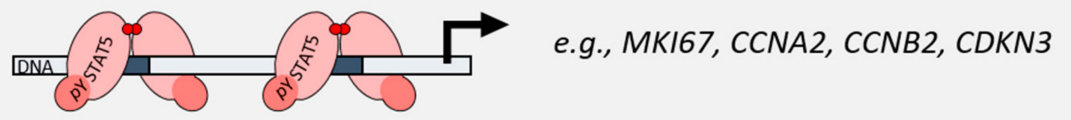

high affinity sites

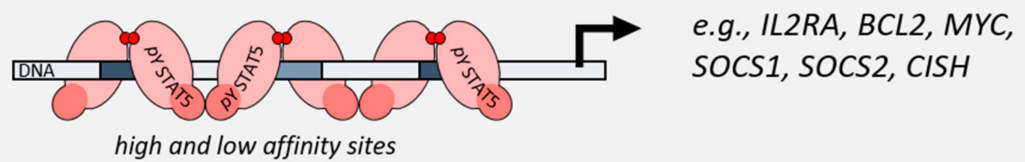

b

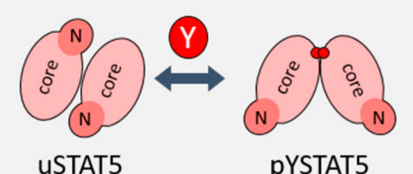

unphosphorylated phosphorylated

dimer dimer high and low affinity sites

Figure 1. Functions of STAT5. (a) Domain structure of STAT5. Position of the critical activating tyrosine phosphorylation site is depicted with Y. ND-N-domain; CCD-coiled-coil domain; DBD—DNA-binding domain; L-linker; SH2-SH2 domain; TAD—transactivation domain. (b) Conformational changes of STAT5 from an unphosphorylated antiparallel dimer (USTAT5) to a phosphorylated parallel dimer (pYSTAT5). (c) Dimer and oligomer conformations of STAT5 result in binding to GAS sites on DNA with different affinities, resulting in expression of different genes. Examples of dimer versus tetramer target genes are incorporated from [32,33].

Interestingly, the $\mathrm{SH} 2$ domain of the hyperactivated gain-of-function variant STAT5B ${ }^{\mathrm{N} 642 \mathrm{H}}$ was also crystallized and compared to wild type human STAT5B. The crystal structure revealed two conformations of the mutant SH2 domain: one conformation is more closed, potentially allowing longer tyrosine phosphorylation lifetimes by blocking phosphatase attack. The other conformation, preserved in the crystal structure, revealed a more open conformation, which could facilitate phospho-peptide or protein interactions leading to hyperactivation [34].

Interestingly, the functions of STAT proteins are not limited to their state as phosphorylated dimers. Unphosphorylated STAT dimers (USTAT), as well as tetramer/oligomer conformations, are involved in the functionality of some STATs [32,35]. Two phosphorylated dimers can form tetramers via their $\mathrm{N}$-terminal oligomerization domains. This interaction stabilizes DNA binding and allows attraction of the tetramers to low-affinity sites, thereby providing altered binding selectivity and fine-tuning of transcriptional responses [36] (Figure 1c).

STAT5 is particularly known for forming oligomers, a function shared with STAT1 and STAT4. In contrast, STAT3 shows weaker tetramer formation upon activation. STAT2 and STAT6 were not reported to form oligomers in cellulo [32,37-39]. However, yeast hybridization assays showed that recombinant $\mathrm{N}$-domains of all STATs are able to self-dimerize [40]. Interestingly, this interaction is clearly homotypic, which might facilitate individual functions of different STATs. In addition, recombinant STAT2 and STAT6 N-domains can form oligomers with the same affinity as other STAT members, but this was not observed in cellulo [40].

The N-terminus also plays an important role in the function of STAT3: it mediates dimerization of uSTAT3, whereas for phosphorylated STAT3 (pYSTAT3) it can enable tetramerization [41,42]. Interestingly, oligomerization of STAT3 is not commonly observed in cellulo. Still, expression of certain genes like A2M ( $\alpha 2$-macroglobulin) was shown to depend on an $\mathrm{N}$-domain interaction of STAT3 [42].

$\mathrm{Hu}$ et al. showed that in STAT3 ${ }^{-/}$MEFs, exogenous expression of an N-terminally truncated STAT3 protein leads to a decrease in expression of a small subset of genes, compared to expression of wild type STAT3 [43]. Not surprisingly, mutated STAT3 ${ }^{\mathrm{Y} 705 \mathrm{~F}}$, which is unable to become phosphorylated 
and to form parallel dimers, significantly affected global gene expression. However, certain genes (e.g., MRAS, MET) were still activated even by uSTAT3 [44]. Interestingly, STAT3 ${ }^{\mathrm{Y} 705 \mathrm{~F}}$ was able to weakly bind to selected promoters and to induce gene expression, thereby promoting an anti-viral, anti-proliferative effect in response to interferon stimulation. It would be interesting to determine if this activity is connected to the heterodimerization of STAT3 with STAT1 or if it is fully mediated through uSTAT3 [45]. uSTAT3 was also reported to be involved in interactions and complex formation with unphosphorylated nuclear factor kappa-light-chain-enhancer of activated B cells (NF- $\mathrm{KB}$ ), which resulted in activation of a subset of NF- $\mathrm{kB}-$ dependent genes. Of note, the authors showed an additional subset of uSTAT3-dependent, but NF-KB-independent genes [46].

Timofeeva et al. showed that USTAT3 plays a repressive role in the apoptosis of cancer cells and that inhibition of STAT3 N-domain functions can abolish this repressive effect. Treatment with the STAT3 N-domain peptidomimetic, ST3-H2A2, hindered STAT3 binding to the regulatory domains of various genes, including the gene for the proapoptotic C/EBP-homologous protein (CHOP). This, in turn, led to a decrease in the heterochromatin mark H3K9me3 in the promoter region of this gene [47]. uSTAT5 is mostly localized in the cytoplasm in the form of anti-parallel dimers. In mammalian cells, cytoplasmic uSTAT5 was shown to associate with and stabilize the Golgi apparatus [48]. On the other hand, a smaller proportion of USTAT5 was also found in the nucleus where it colocalizes with the transcriptional repressor CTCF, thereby diminishing megakaryocyte differentiation via competition for DNA binding with the transcription factor ERG [35]. Additionally, there is evidence that uSTAT5 can migrate into the nucleus and bind heterochromatin protein $1 \alpha(\mathrm{HP} 1 \alpha)$ to promote the formation of heterochromatin. This leads to repression of various genes, among which many are found to be involved in cancer development [49].

One function of the STAT5 N-terminal domain involves docking of STAT5 to receptors. For example, it was shown that STAT5 interacts via the $\mathrm{N}$-terminal domain with the glucocorticoid receptor [50]. The N-domain of STAT5 has an O-GlcNAc modification site on threonine 92. For STAT5A, it was shown that the presence of this glucose-derived modification within the $\mathrm{N}$-domain is essential for full activation, suggesting cross-talk between the $\mathrm{N}$ - and $\mathrm{C}$-domains and involvement of the $\mathrm{N}$-domain in the regulation of metabolic functions in cells [51].

Another function of the STAT5 N-domain is mediating STAT5 tetramerization. Tetramerization was shown to be essential for proper T-cell development and was also found to be associated with enhanced activity of STAT5 as an oncogene [32]. STAT5 tetramers can bind to different motifs compared with STAT5 dimers, to induce or repress gene expression (Figure 1c) [52]. It was shown that deletion of the $\mathrm{N}$-domain of STAT5 results in an absence of $c-M Y C, B C L-2$ and cyclin D2 expression upon stimulation, indicating that oligomers can induce a different subset of genes than dimers [32]. Extensive studies by Lin et al., using a mutated STAT5 N-domain that is unable to form oligomers in vivo, defined the oligomer-dependent subset of genes as well as the importance of oligomerization in NK cell maturation [33,52].

The STAT5 N-domain was shown to be essential for leukemogenic transformation. Deletion of the N-domain or mutation of the O-GlcNAc-modified residue (T92A) abolished the initiation of the leukemic disease driven by gain-of-function STAT5A [32,51,53]. This suggests an important function of the STAT5 N-domain in oncogenic transformation and it proposes that the $\mathrm{N}$-domain can serve as a novel targeting interface of STAT5.

\section{Role of STAT3/5 in Chromatin Landscape}

Over the last years, it was shown that STAT3 and STAT5 transcription factors can influence gene expression not only directly by binding to gene promoters but also through recruiting various chromatin remodelers and influencing gene expression and chromatin states on the global level. STAT3/5 can change the chromatin landscape in a cell by recruiting various chromatin-remodeling or DNA-modifying enzymes to the DNA, such as histone acetyltransferases (HATs), histone deacetylases (HDACs), as well as ten-eleven translocation methylcytosine dioxygenase 1/2 (TET1/2) or DNA 
(cytosine-5)-methyltransferase 1 (DNMT1) [54-57] (Figure 2a,b). These interactions influence euor hetero-chromatin formation or DNA methylation, thereby activating or repressing transcription. The STATs themselves can also be post-translationally modified by these enzymes: for example, methylation of STAT3 by the enhancer of zeste homolog 2/polycomb repressive complex 2 (EZH2/PRC2), or acetylation of STAT3 and STAT5 by CREB-binding protein (CBP)/p300 [1].

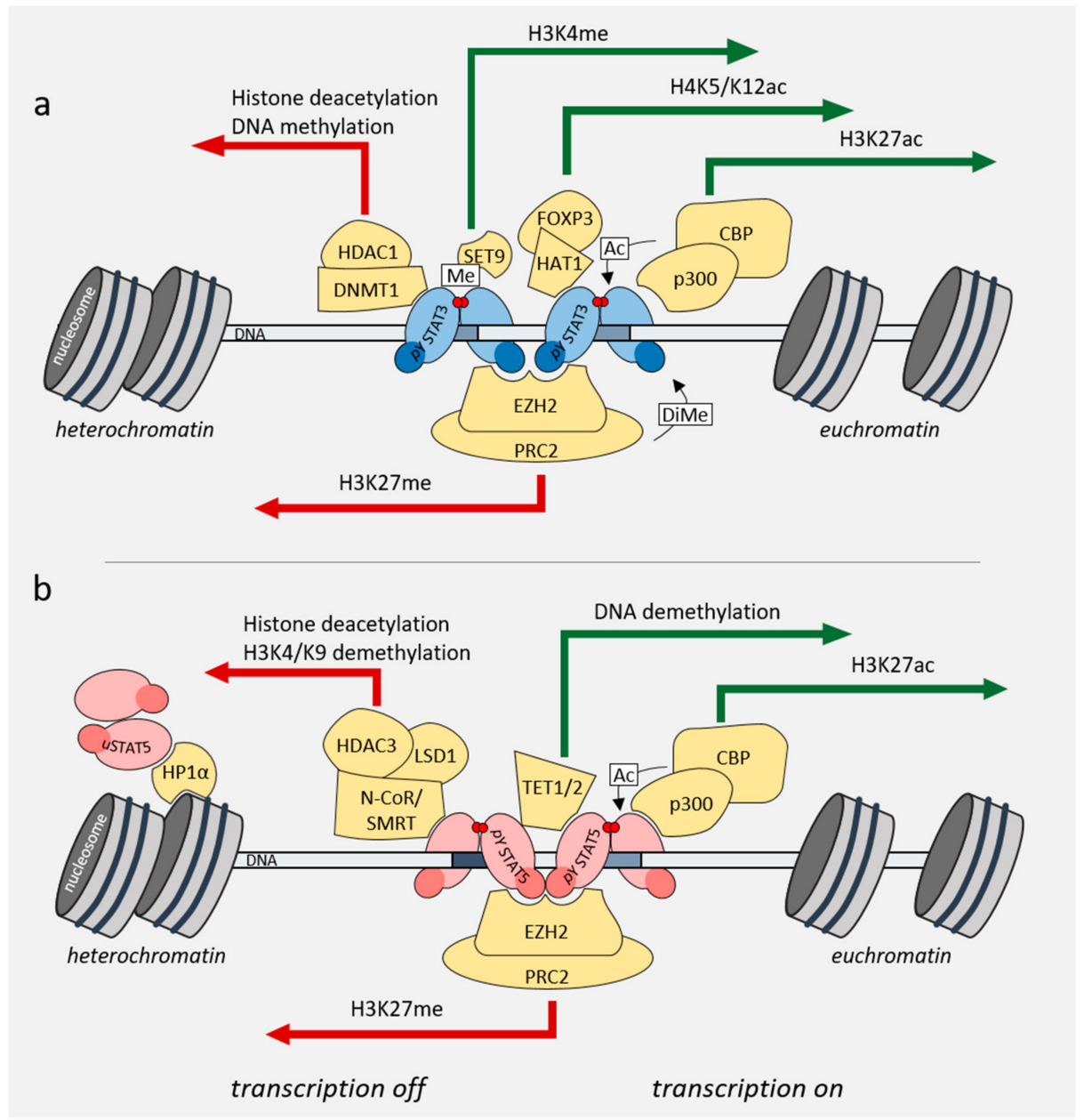

Figure 2. Role of STAT3/5 in regulating the chromatin landscape. (a) pYSTAT3 interacts with and recruits chromatin remodelers, and thereby promotes changes in chromatin compaction. (b) uSTAT5 and pYSTAT5 interact with different chromatin remodelers, thereby promoting chromatin changes associated with euchromatin (green arrows) or heterochromatin (red arrows) formation.

In the case of STAT3, acetylation or methylation at different residues leads to different activity and functionality of the protein (Figure 2a) [12]. For example, acetylation of STAT3 by CBP/p300 on lysine 685 in the C-terminal domain increases the DNA binding ability of STAT3 [58]. On the other hand, methylation of phosphorylated, promoter-bound STAT3 on lysine 140 by SET9 reduces its transcriptional activity on a subset of target genes [59], whereas dimethylation on lysine 49 by $\mathrm{EZH} 2$ is required for the expression of IL-6-dependent genes [60]. It was also shown that STAT3 binds to the promoter of the tyrosine phosphatase SHP-1 and recruits DNMT1 and HDAC1 to silence its transcription in cutaneous T-cell lymphoma (CTCL) and in ALK ${ }^{+}$ALCL cell lines [57]. In regulatory T-cells, STAT3 was found to cooperate with FoxP3 and HAT1 to induce expression of IL-10 [61].

STAT5 is also known to recruit chromatin remodelers (Figure 2b). One example of such an interaction is co-activation of STAT5 by HAT nuclear receptor coactivator 1 (NCoA-1). NCoA-1 and STAT5A transiently co-transfected in HEK293T cells were shown to interact with each other by co-immunoprecipitation. This interaction required amino acids 751 to 753 in the STAT5 transactivation 
domain, which is conserved in both STAT5A and STAT5B [54]. Furthermore, in Ba/F3 cells, STAT5A was shown to interact with HDAC3 and lysine-specific demethylase 1 (LSD1), thereby activating or repressing gene expression [55]. The interaction between STAT5A and LSD1/HDAC3 is mediated by the STAT5A DNA-binding domain, linker and its SH2 domain and HDAC3 can additionally interact with the coiled-coil domain of STAT5A [55]. STAT5 influences not only the acetylation but also the methylation status of its surroundings, for example by recruiting TET1/2 to the Foxp 3 locus. This causes demethylation of the locus and plays an important role in regulatory T-cell differentiation [56].

Mandal et al. showed that during B-cell maturation and B-cell receptor rearrangement, gene regions required for immunoglobulin $\mathrm{k}$ light chain expression are silenced by histone methyltransferase EZH2-STAT5 tetramer interactions (Figure 2b) [62]. This underlines the importance of the STAT5 $\mathrm{N}$-terminal domain and tetramerization during B-cell development or as a mechanism for acute B-cell leukemia initiation or progression.

\section{Direct STAT Targeting of the SH2 Domain}

Treating cancers with hyperactivated or mutated STAT3 and STAT5 is currently achieved by targeting upstream kinases. However, despite tyrosine kinase inhibitors being significantly superior to classical chemotherapy, their application often causes severe side-effects and development of resistance [63]. Therefore, development of more specific and effective inhibitors that also target downstream components of hyperactivated pathways is desirable to overcome limitations of current strategies. In the following section, we focus specifically on small-molecule inhibitors of the STAT3/5 SH2 domains.

\subsection{STAT3 Inhibitors}

The first two small-molecule STAT3 inhibitors were fragment-sized compounds discovered by random biochemical and virtual screening. One compound, Stattic, was identified in a high-throughput screen of a diverse chemical library (Figure 3a) [64]. Another anthraquinone-based compound, STA-21 (Figure $3 b$ ), was discovered by structure-based virtual screening against the published X-ray structure of STAT3 $\beta[65,66]$. Later, multiple analogs of STA-21 were reported, such as LLL-3 and LLL-12 (Figure 3c,d) $[67,68]$. Recently, several different chemotypes have emerged, often consisting of ring systems connected by amide-containing linkers. An important step forward was the identification of the salicylic acid moiety that is an efficient bioisostere of the phosphate group required for STAT-STAT dimer formation. Salicylic acid analogs were described as potent STAT3 inhibitors as exemplified by the inhibitor S31-201 (Figure 3e), as well as its optimized successors, SF-1-066, SF-1-121 and S31-1757 (Figure 3f,g) [69-71].

Virtual screening was useful to find new chemotypes of STAT3 inhibitors. Matsuno et al. and $\mathrm{Xu}$ et al. described further double-digit micromolar STAT3 inhibitors, STX-0119 and Cpd30-12 (in cellular assays; Figure 3h,i) [72,73]. Furthermore, a number of natural products (or analogs thereof) and antioxidants have been proposed and identified as potential inhibitors of STATs, most particularly STAT3, displaying even single-digit micromolar inhibitory activities [74-78].

Another noteworthy study reported an in silico fragment-based drug discovery approach, resulting in a single-digit micromolar STAT3 inhibitor, LY5 (in both cell-free and cell-based assays; Figure 3j), targeted towards the SH2 domain [79]. Recently, Zhang et al. identified benzothiazole as a novel scaffold among STAT3 inhibitors, resulting from a virtual screening of more than 200,000 compounds by a multistep protocol. In this study, four compounds were confirmed experimentally, with the benzothiazole-based compound 9 (Figure $3 \mathrm{k}$ ) displaying a single-digit micromolar $\mathrm{IC}_{50}$ value against the IL-6/STAT3 signaling pathway [80]. Two further analogs were discovered by a similarity-based hit expansion. When the number of known STAT3 inhibitors reached a sufficient level to compile a training set for a three-dimensional (3D) pharmacophore-based virtual screening study, Leung et al. screened a small in-house dataset and tested five compounds, out of which one (Cpd1, Figure 31) was experimentally confirmed in multiple STAT3-related endpoints [81]. 


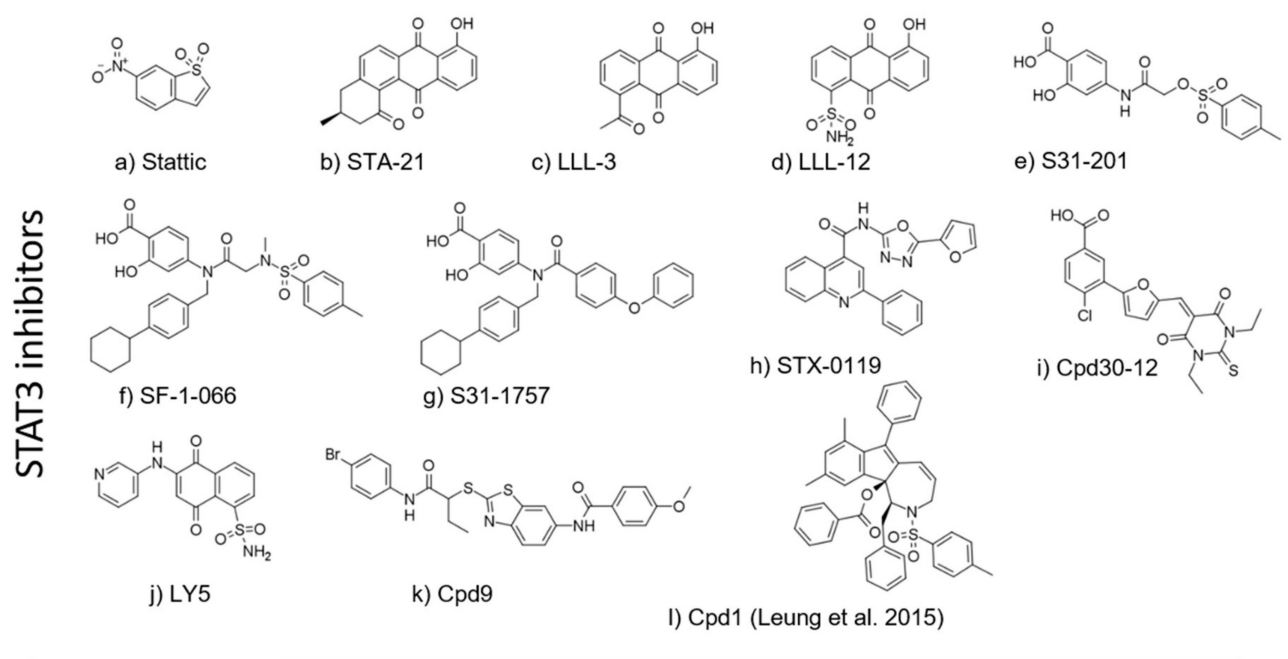

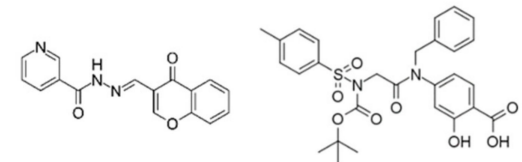

m) Cpd1 (Müller et al. 2008b)

n) SF-1-088

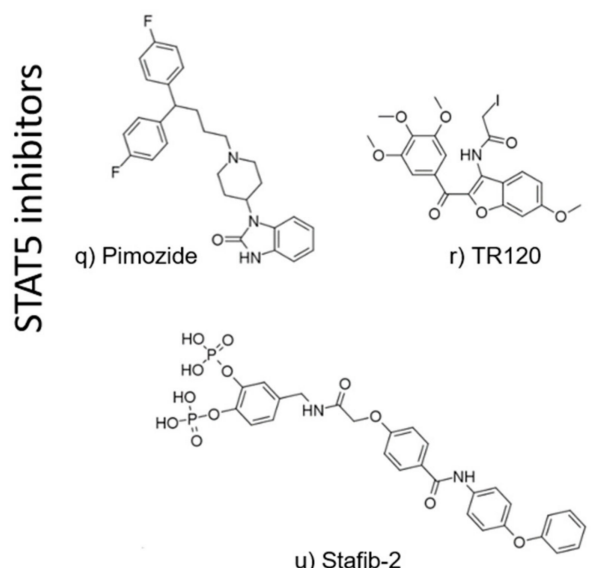

u) Stafib-2

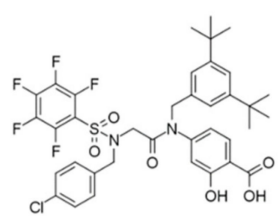

o) $13 a$

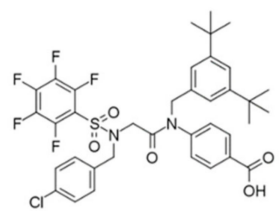

p) AC-4-130
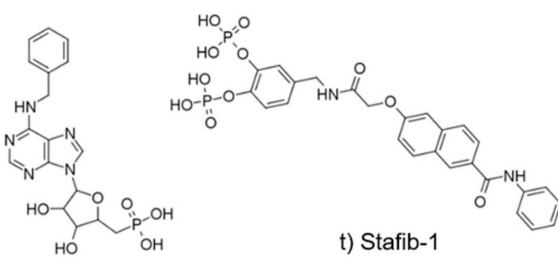

s) IST5-002

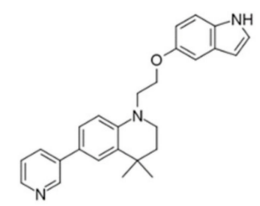

v) Cpd17f

Figure 3. Chemical structures of STAT3 and STAT5 inhibitors (in their order of citation in the main text). Compounds with identical names (Cpd1) are further specified by citations.

The compounds OPB-31121, OPB-51602 and OPB-111077, which are substances from Otsuka Pharmaceuticals, were designed to inhibit STAT3 phosphorylation in cancer cell lines and xenograft models by targeting the STAT3 SH2 domain. Available studies with OPB-51602 indicate induction of STAT3 aggregation in autophagosomes. Additionally, there has been controversy on the activity of OPB-51602 against mitochondrial STAT3. Two of these STAT3 SH2 inhibitors, OPB-31121 and OPB-51602, were already tested in phase I/II clinical trials for solid tumors, non-Hodgkin lymphoma, myeloma and other hematopoietic malignancies [81]. In these studies, the compounds were promising based on a relatively long half-life, suggesting the possibility of a reduced dosing regimen to limit toxic side effects. However, the clinical trials for both lead structure drugs were terminated due to minimal antitumor activity, toxicity issues and poor pharmacokinetics. Another STAT3 inhibitor, OPB-111077, has completed a phase I trial for solid cancers (NCT02250170), and phase I/II trials are recruiting for acute myeloid leukemia (AML) (NCT03197714) and other refractory tumors (NCT03158324) $[82,83]$. Efficacies of the above-mentioned STAT3 SH2 inhibitors in vitro and in vivo are summarized in Table 1. 
Table 1. Small-molecule compounds targeting the STAT3 SH2 domain.

\begin{tabular}{|c|c|c|c|c|c|c|c|}
\hline \multirow{2}{*}{ Cpd } & \multicolumn{2}{|c|}{ Protein-Based } & \multicolumn{3}{|c|}{ Cell-Based } & \multirow{2}{*}{$\begin{array}{c}\text { In Vivo } \\
\text { Application } \\
\text { Tested }\end{array}$} & \multirow{2}{*}{ Refs. } \\
\hline & Assay & $\begin{array}{c}\mathrm{IC}_{50} \text { or } \mathrm{Ki} \\
{[\mu \mathrm{M}]}\end{array}$ & Cell Line & Readout & $\begin{array}{c}\mathrm{IC}_{50} \\
{[\mu \mathrm{M}] \mathrm{a}}\end{array}$ & & \\
\hline \multirow{3}{*}{ Stattic } & \multirow{3}{*}{ pY binding } & \multirow{3}{*}{5.1} & $\begin{array}{c}\text { HepG2, } \\
\text { MDA-MB-231 }\end{array}$ & viability & 3.8 & & \multirow{3}{*}[64,84,85]{} \\
\hline & & & RAW264.7 & pYSTAT3 & s (20) & $\begin{array}{l}\text { Osteoclasto } \\
\text { genesis in } \\
\text { C57/BL6 mice } \\
(10 \mathrm{mg} / \mathrm{kg})\end{array}$ & \\
\hline & & & $\begin{array}{l}\text { M-SCC-17B, } \\
\text { OSC-19, Cal33, } \\
\text { UM-SCC-22 }\end{array}$ & viability & $2.2-3.5$ & $\begin{array}{l}\text { Head and neck } \\
\text { cancer xenograft } \\
(50 \mathrm{mg} / \mathrm{kg})\end{array}$ & \\
\hline \multirow{2}{*}{ STA-21 } & & & Caov-3 & reporter assay & s (20) & \multirow{2}{*}{$\begin{array}{l}\text { Psoriatic disease } \\
\text { in mouse model } \\
\text { and phase I in } \\
\text { clinical trial } \\
\text { (NCT0104794) }\end{array}$} & \multirow{2}{*}[66,86]{} \\
\hline & & & $\begin{array}{l}\text { MDA-MB-435s, } \\
\text { MDA-MB-468, } \\
\text { MDA-MB-231 }\end{array}$ & $\begin{array}{l}\text { DNA binding, } \\
\text { viability }\end{array}$ & s (20) & & \\
\hline \multirow[t]{2}{*}{ LLL-3 } & & & $\begin{array}{c}\text { U373, } \\
\text { MDA-MB-231 }\end{array}$ & DNA binding & s (20) & \multirow{2}{*}{$\begin{array}{c}\text { Xenograft } \\
\text { glioblastoma } \\
(50 \mathrm{mg} / \mathrm{kg})\end{array}$} & \multirow[t]{2}{*}{ [68] } \\
\hline & & & MDA-MB-231 & reporter assay & s (20) & & \\
\hline LLL-12 & & & $\begin{array}{c}\text { MDA-MB-231, } \\
\text { SK-BR-3, } \\
\text { PANC-1, HPAC, } \\
\text { U87, U373, } \\
\text { A549 }\end{array}$ & $\begin{array}{c}\text { viability, } \\
\text { pYSTAT3, } \\
\text { reporter assay }\end{array}$ & $0.16-3.09$ & $\begin{array}{c}\text { Glioblastoma, } \\
\text { breast cancer } \\
\text { xenograft } \\
(2.5,5 \mathrm{mg} / \mathrm{kg}) \\
\text { Lung cancer } \\
\text { xenograft } \\
(20,10 \mathrm{mg} / \mathrm{kg})\end{array}$ & {$[67,87]$} \\
\hline \multirow{3}{*}{ S31-201 } & & & NIH 3T3/v-Src & DNA binding & 86 & \multirow{3}{*}{$\begin{array}{c}\text { Xenograft breast } \\
\text { cancer } \\
(5 \mathrm{mg} / \mathrm{kg})\end{array}$} & \multirow{3}{*}[69,71]{} \\
\hline & & 80 & $\begin{array}{l}\text { MDA-MB-468, } \\
\text { MDA-MB-231 }\end{array}$ & pYSTAT3 & s (100) & & \\
\hline & & & $\begin{array}{c}\text { DU145, } \\
\text { MDA468, } \\
\text { OCI-AML-2 }\end{array}$ & viability & $28-112$ & & \\
\hline \multirow{2}{*}{ SF-1-066 } & \multirow{2}{*}{$\mathrm{FP}$} & \multirow{2}{*}{20} & NIH 3T3/v-Src & DNA binding & 35 & & \multirow{2}{*}{ [69] } \\
\hline & & & $\begin{array}{c}\text { DU145, } \\
\text { MDA468, } \\
\text { OCI-AML-2 }\end{array}$ & viability & $17-37$ & & \\
\hline \multirow{2}{*}{ S31-1757 } & \multirow{2}{*}{ pY binding } & \multirow{2}{*}{13.5} & HEK293 & CoIP & s (50) & & \multirow{2}{*}{ [88] } \\
\hline & & & $\begin{array}{l}\text { MDA-MB-468, } \\
\text { A549 }\end{array}$ & $\begin{array}{c}\text { pYSTAT3, } \\
\text { reporter assay }\end{array}$ & s (50) & & \\
\hline \multirow{2}{*}{ STX-0119 } & & & $\mathrm{HeLa}$ & reporter assay & 74 & \multirow{2}{*}{$\begin{array}{l}\text { Xenograft } \\
\text { lymphoma } \\
(160 \mathrm{mg} / \mathrm{kg})\end{array}$} & \multirow{2}{*}{ [73] } \\
\hline & & & HEK293 & $\begin{array}{l}\text { FRET-based } \\
\text { dimerization }\end{array}$ & s (50) & & \\
\hline Cpd30-12 & $\begin{array}{c}\mathrm{pY} \\
\text { binding }\end{array}$ & 114 & $\begin{array}{c}\text { HepG2, } \\
\text { MEF/GFP-Stat3 } \alpha, \\
\text { MDA-MB-468, } \\
\text { MDA-MB-231, } \\
\text { MBA-MD-435, } \\
\text { MCF7 }\end{array}$ & $\begin{array}{l}\text { pYSTAT3, } \\
\text { nuclear } \\
\text { translocation, } \\
\text { apoptosis }\end{array}$ & 60 & & [72] \\
\hline \multirow[t]{2}{*}{ LY5 } & \multirow[t]{2}{*}{$\mathrm{FP}$} & \multirow[t]{2}{*}{2.5} & $\begin{array}{l}\text { U2OS, RH30, } \\
\text { RD2, } \\
\text { MDA-MB-231 }\end{array}$ & $\begin{array}{l}\text { viability, } \\
\text { pYSTAT3 }\end{array}$ & $0.52-1.39$ & \multirow{2}{*}{$\begin{array}{c}\text { Xenograft breast } \\
\text { cancer } \\
(5 \mathrm{mg} / \mathrm{kg})\end{array}$} & {$[79,89]$} \\
\hline & & & $\begin{array}{l}\text { UW426, } \\
\text { UW288-1, } \\
\text { DAOY }\end{array}$ & pYSTAT3 & $\mathrm{s}(0.5)$ & & \\
\hline Cpd9 & & & HepG2/STAT3 & $\begin{array}{l}\text { reporter assay, } \\
\text { pYSTAT3 }\end{array}$ & 3.57 & & [80] \\
\hline & & & MDA-MB-468 & viability & 8.83 & & \\
\hline Cpd1 & FP & $\sim 10$ & HeLa & $\begin{array}{l}\text { reporter assay, } \\
\text { DNA binding }\end{array}$ & $\sim 10$ & & [81] \\
\hline
\end{tabular}




\subsection{STAT5 Inhibitors}

The first landmark papers on STAT5 SH2 domain inhibitors were published in 2008 by the Berg group. These were driven by the development of a robust high-throughput screening assay for STAT5B inhibitors [90,91]. This facilitated the discovery of chromone-based STAT5B inhibitors as well as a nicotinoyl hydrazine derivative, Cpd1 (Figure 3m), as a selective STAT5B inhibitor (in comparison to STAT1 and STAT3) [91].

Later, four salicylic acid-based compounds (including the single-digit micromolar inhibitor SF-1-088, Figure 3n) were identified by the Gunning group [92]. These hits were optimized to generate the STAT5B inhibitor, 13a, through a structure-guided approach (Figure 3o). Studies with 13a have shown it can effectively reduce pYSTAT5B levels in cellulo, and follow up thermal stability studies showed an inhibitor-induced reduction in STAT5 stability and the potential to block de novo phosphorylation $[28,93,94]$. Additional studies extended this work to demonstrate AML cell viability inhibition with AC-4-130, a further improved lead compound (Figure 3p) [95].

It is worth noting that in a 2011 study, Nelson et al. identified the neuroleptic drug pimozide as a STAT5 inhibitor (Figure 3q). However, recent studies have linked pimozide with proteolysis upstream of STAT5, rather than direct binding [96]. Nonetheless, the discovery later prompted Rondanin et al. to synthesize and screen a series of pimozide derivatives, two of which have surpassed the cytotoxic potency of pimozide as evaluated against imatinib-resistant BCR-ABL-expressing leukemia cells [97]. In 2016, the same group synthesized and tested 22 iodoacetamide-containing heterocycles for STAT5 inhibition, many of which (including TR120, Figure 3r) were confirmed experimentally in an in vitro cytotoxicity assay, although direct binding to STAT5 was not examined [98].

In 2015, Liao et al. conducted a large scale structure-based virtual screening campaign for STAT5A/B inhibitors [99]. Using a STAT3 based homology model of STAT5, the authors docked $\sim 30$ million compounds to the dimerization interface on the SH2 domain [65]. The top 30 hits were evaluated in various cell lines, with IST5-002 (Figure 3s) identified as a lead compound that inhibited STAT5A and STAT5B in the low micromolar range in cellulo. However, the first STAT5A/B gene product-selective inhibitor was developed in the same year, by the Berg group. Stafib-1 (Figure 3t), a catechol type bisphosphate-containing nanomolar STAT5B inhibitor (as evaluated in a fluorescence polarization assay), was identified by structure-based virtual screening against the SH2 domain of a STAT5B model derived from the structure of unphosphorylated STAT5A [30,100]. This compound was recently optimized into the single-digit nanomolar inhibitor Stafib-2 (Figure 3u) using a structure-based approach [101]. Stafib-2, similar to its predecessor, has shown high selectivity for STAT5B compared to other STAT proteins, including STAT5A. The hydrophilicity of the phosphate motifs was reduced by generating a pro-drug precursor, which employs pivaloyloxymethyl esters to conceal the negatively charged phosphate groups and increase cell penetrance. Recently, Natarajan et al. reported Stafia-1, a selective inhibitor for STAT5A, discovered by docking-based screening [102]. Tested applications for STAT5 inhibitors in vivo and in vitro are summarized in Table 2.

Berg et al. also identified nucleotide scaffolds with potentially selective inhibition properties against STAT5B. Although, the $\mathrm{IC}_{50}$ values in a fluorescence polarization assay are in the high micro-molar range $\left(\mathrm{STAT5B}, \mathrm{IC}_{50}[\mathrm{ATP}]=97.4 \pm 0.9 \mu \mathrm{M}, \mathrm{IC}_{50}[\mathrm{GTP}]=95.5 \pm 3.2 \mu \mathrm{M}\right.$; STAT5A, $\left.\mathrm{IC}_{50}[\mathrm{ATP}]=443 \pm 34 \mu \mathrm{M}, \mathrm{IC}_{50}[\mathrm{GTP}]=311 \pm 46 \mu \mathrm{M}\right)$, these concentrations are still well below intracellular ATP concentrations $(>2 \mathrm{mM})$. It would be of high interest to validate these findings in cellulo. These results suggest STAT5B may also play a role in directly coupling gene expression to cellular metabolism, and also highlight a potential new targeting strategy using nucleotide-based inhibitor scaffolds [104]. Recently, a novel mechanism of selectively blocking STAT5B activity was proposed through protein-mediated Mannich reactions. The ligand-efficient 4-amino-furazan-3-carboxylic acid molecule $\left(\mathrm{K}_{\mathrm{d}}=420 \mu \mathrm{M}\right.$, STAT5B fluorescent polarization assay) was identified from a library of 17,000 compounds. This phosphate-mimetic reacts with $1 H$-tetrazoles in the presence of formaldehyde, and this reaction only proceeds in acidic conditions ( $\mathrm{pH}$ 5.0). However, the addition of MBP-tagged STAT5B-SH2 domain peptide catalyzed the reaction even at physiological conditions. 
Although tetrazoles were not active against STAT5B $(>10 \mathrm{mM})$, the ligation products showed substantial activity, which the authors attribute to super-additive binding interactions. Intracellular physiological concentrations of formaldehyde also emphasize the viability of this molecule as a STAT inhibitor and the utility of bio-catalytic Mannich reactions [105].

Table 2. Small-molecule compounds targeting the STAT5 SH2 domain.

\begin{tabular}{|c|c|c|c|c|c|c|c|}
\hline \multirow{2}{*}{ Cpd } & \multicolumn{2}{|c|}{ Protein-Based } & \multicolumn{3}{|c|}{ Cell-Based } & \multirow{2}{*}{$\begin{array}{c}\text { In Vivo } \\
\text { Application Tested }\end{array}$} & \multirow{2}{*}{ Refs. } \\
\hline & Assay & $\begin{array}{c}\mathrm{IC}_{50} \text { or } \mathrm{K}_{\mathrm{i}} \\
{[\mu \mathrm{M}]^{\mathrm{a}}}\end{array}$ & Cell Line & Readout & $\begin{array}{l}\mathrm{IC}_{50} \\
{[\mu \mathrm{M}]^{\mathrm{a}}}\end{array}$ & & \\
\hline Cpd1 & FP & 47 & $\begin{array}{l}\text { K562, } \\
\text { Daudi }\end{array}$ & $\begin{array}{l}\text { DNA binding, } \\
\text { pYSTAT5 }\end{array}$ & s (100) & & [91] \\
\hline SF-1-088 & FP & 8.3 & K562,MV4-11 & $\begin{array}{l}\text { viability, } \\
\text { pYSTAT5 }\end{array}$ & $80-77$ & & [92] \\
\hline \multirow[t]{2}{*}{$13 a$} & & & K562 & $\begin{array}{l}\text { pYSTAT5, } \\
\text { viability }\end{array}$ & s (15) & & \multirow[t]{2}{*}[28,93,94]{} \\
\hline & & & MV4-11 & viability & 3.5 & & \\
\hline \multirow[t]{2}{*}{ AC- $4-130$} & \multirow[t]{2}{*}{$\begin{array}{c}\text { binding } \\
\text { (thermal shift) }\end{array}$} & \multirow[t]{2}{*}{ s (100) } & $\begin{array}{c}\text { MV4-11, } \\
\text { MOLM-13 }\end{array}$ & $\begin{array}{c}\text { viability, } \\
\text { reporter assay }\end{array}$ & $1.7-1.9$ & \multirow[t]{2}{*}{$\begin{array}{l}\text { AML xenograft } \\
(25 \mathrm{mg} / \mathrm{kg})\end{array}$} & \multirow[t]{2}{*}{ [95] } \\
\hline & & & $\begin{array}{c}\text { AML } \\
\text { patient } \\
\text { samples }\end{array}$ & viability & $1.6-4.9$ & & \\
\hline Pimozide & & & $\begin{array}{l}\text { KU812, } \\
\text { K562 }\end{array}$ & $\begin{array}{l}\text { pYSTAT5, } \\
\text { viability }\end{array}$ & s (5) & $\begin{array}{l}\text { Approved by } \\
\text { FDA as } \\
\text { antipsychotic drug }\end{array}$ & [96] \\
\hline \multirow{2}{*}{ TR120 } & & & \multirow{2}{*}{ K562 } & viability & 0.12 & & \multirow{2}{*}{ [98] } \\
\hline & & & & apoptosis & 0.45 & & \\
\hline \multirow[t]{2}{*}{ IST5-002 } & & & $\begin{array}{l}\text { K562, } \\
\text { DU145, }\end{array}$ & $\begin{array}{l}\text { pYSTAT5, } \\
\text { reporter assay, } \\
\text { DNA binding }\end{array}$ & s (5) & \multirow{2}{*}{$\begin{array}{c}\text { Prostate cancer } \\
\quad \text { xenograft } \\
(25,50,100 \mathrm{mg} / \mathrm{kg})\end{array}$} & \multirow[t]{2}{*}{ [99] } \\
\hline & & & $\begin{array}{l}\text { PC-3, } \\
\text { COS-7 }\end{array}$ & viability & 3.5 & & \\
\hline Stafib-1 & FP & 0.044 & K562 & pYSTAT5 & s (3) & & [100] \\
\hline Stafib-2 & FP & 0.009 & K562 & pYSTAT5 & 1.5 & & [101] \\
\hline Cpd17f & & & $\begin{array}{c}\text { K562, } \\
\text { KU812, } \\
\text { KG1a, } \\
\text { MV4-11 }\end{array}$ & $\begin{array}{l}\text { viability, } \\
\text { pYSTAT5 }\end{array}$ & $2.6-22.7$ & & [103] \\
\hline
\end{tabular}

A study by Juen et al. reported the optimization of the STAT5 inhibitor, Cpd17f (Figure 3v) [103]. Interestingly, the initial hit was originally intended for PPAR $\alpha / \gamma$ inhibition, while the inhibition of STAT5 phosphorylation was an off-target effect [106]. Since the compound did not inhibit PPARs, but showed a considerable inhibition of STAT5 phosphorylation, 18 analogs were synthesized and tested in a cell-based assay. As shown by Brachet-Bottineau et al., in this special issue, Cpd17f inhibits STAT5B protein expression through non-transcriptional mechanisms. However, as with the majority of the aforementioned inhibitors, further confirmatory assays demonstrating the mechanism of action are required. Although multiple studies using molecular modeling or computational dynamics have been insightful in STAT5 inhibitor design, protein-inhibitor complexes characterized with atomic-level resolution, such as through X-ray crystallization, would provide a clearer understanding of target engagement in efficacy and selectivity studies.

Apart from these efforts targeting the SH2 domain of STAT3 or STAT5 molecules, studies have also reported describing approaches to block STAT3/5 DNA binding or the use of antisense RNA interference, discussed further in this special issue with separate overview articles. 


\section{Conclusions}

STAT3 and STAT5 are the key nodes in transcriptional activation downstream of cytokine or kinase action in multiple cancers. This makes them attractive, but challenging targets for drug development. Recent findings expand on a previously rather simplistic understanding of STAT3/5 function as parallel phosphorylated dimers. It has become evident that higher-order conformations of pYSTATs, as well as USTAT, are involved in chromatin landscape shaping, thereby acting beyond classical transcription factors. This knowledge provides a deeper understanding of their role in cancer biology, which together with various targeting efforts, will open novel therapeutic options.

Funding: C.W., H.A.N. and R.M. are supported by the Austrian Science Fund (FWF) [SFB-F04707, SFB-F06105, and under the frame of ERA PerMed (I 4218-B) and ERA-NET (I 4157-B)]. R.M., H.A.N. and A.O. were also generously supported by a private donation from Liechtenstein. D.B. and G.M.K. are supported by OTKA K 116904 (National Research, Development and Innovation Office, Hungary). P.T.G. is supported by research grants from NSERC (RGPIN-2014-05767), CIHR (MOP-130424, MOP-137036), Canada Research Chair (950-232042), Canadian Cancer Society (703963), Canadian Breast Cancer Foundation (705456) and infrastructure grants from CFI (33536) and the Ontario Research Fund (34876). M.H. was also supported by the EU Transcan-2 consortium 'ERANET-PLL' and by the ERA PerMed consortium 'JAKSTAT-TARGET'.

Acknowledgments: Open Access Funding by the Austrian Science Fund (FWF).

Conflicts of Interest: Authors declare no conflict of interest.

\section{References}

1. Wingelhofer, B.; Neubauer, H.A.; Valent, P.; Han, X.; Constantinescu, S.N.; Gunning, P.T.; Müller, M.; Moriggl, R. Implications of STAT3 and STAT5 signaling on gene regulation and chromatin remodeling in hematopoietic cancer. Leukemia 2018, 32, 1713-1726. [CrossRef] [PubMed]

2. Koromilas, A.E.; Sexl, V. The tumor suppressor function of STAT1 in breast cancer. JAK-STAT 2013, 2, e23353. [CrossRef] [PubMed]

3. Yu, H.; Jove, R. The stats of cancer-New molecular targets come of age. Nat. Rev. Cancer 2004, 4, 97-105. [CrossRef]

4. Meissl, K.; Macho-Maschler, S.; Müller, M.; Strobl, B. The good and the bad faces of STAT1 in solid tumours. Cytokine 2017, 89, 12-20. [CrossRef]

5. Klover, P.J.; Muller, W.J.; Robinson, G.W.; Pfeiffer, R.M.; Yamaji, D.; Hennighausen, L. Loss of STAT1 from Mouse Mammary Epithelium Results in an Increased Neu-Induced Tumor Burden. Neoplasia 2010, 12, 899-905. [CrossRef]

6. Kovacic, B.; Stoiber, D.; Moriggl, R.; Weisz, E.; Ott, R.G.; Kreibich, R.; Levy, D.E.; Beug, H.; Freissmuth, M.; Sexl, V. STAT1 acts as a tumor promoter for leukemia development. Cancer Cell 2006, 10, 77-87. [CrossRef]

7. Godfrey, A.L.; Chen, E.; Massie, C.E.; Silber, Y.; Pagano, F.; Bellosillo, B.; Guglielmelli, P.; Harrison, C.N.; Reilly, J.T.; Stegelmann, F.; et al. STAT1 activation in association with JAK2 exon 12 mutations. Haematologica 2016, 101, e15. [CrossRef]

8. Prutsch, N.; Gurnhofer, E.; Suske, T.; Liang, H.C.; Schlederer, M.; Roos, S.; Wu, L.C.; Simonitsch-Klupp, I.; Alvarez-Hernandez, A.; Kornauth, C.; et al. Dependency on the TYK2/STAT1/MCL1 axis in anaplastic large cell lymphoma. Leukemia 2019, 33, 696-709. [CrossRef]

9. Sanda, T.; Tyner, J.W.; Gutierrez, A.; Ngo, V.N.; Glover, J.; Chang, B.H.; Yost, A.; Ma, W.; Fleischman, A.G.; Zhou, W.; et al. TYK2-STAT1-BCL2 Pathway Dependence in T-cell Acute Lymphoblastic Leukemia. Cancer Discov. 2013, 3, 564. [CrossRef]

10. Furth, P.A. STAT signaling in different breast cancer sub-types. Mol. Cell. Endocrinol. 2014, 382, $612-615$. [CrossRef]

11. Levy, D.E.; Darnell, J.E. STATs: Transcriptional control and biological impact: Signalling. Nat. Rev. Mol. Cell Biol. 2002, 3, 651-662. [CrossRef] [PubMed]

12. Avalle, L.; Camporeale, A.; Camperi, A.; Poli, V. STAT3 in cancer: A double edged sword. Cytokine 2017, 98, 42-50. [CrossRef]

13. Bromberg, J.F.; Wrzeszczynska, M.H.; Devgan, G.; Zhao, Y.; Pestell, R.G.; Albanese, C.; Darnell, J.E., Jr. Stat3 as an Oncogene. Cell 1999, 98, 295-303. [CrossRef] 
14. Corvinus, F.M.; Orth, C.; Moriggl, R.; Tsareva, S.A.; Wagner, S.; Pfitzner, E.B.; Baus, D.; Kaufman, R.; Huber, L.A.; Zatloukal, K.; et al. Persistent STAT3 Activation in Colon Cancer Is Associated with Enhanced Cell Proliferation and Tumor Growth. Neoplasia 2005, 7, 545-555. [CrossRef]

15. Yu, H.; Lee, H.; Herrmann, A.; Buettner, R.; Jove, R. Revisiting STAT3 signalling in cancer: new and unexpected biological functions. Nat. Rev. Cancer 2014, 14, 736. [CrossRef]

16. Mohanty, S.K.; Yagiz, K.; Pradhan, D.; Luthringer, D.J.; Amin, M.B.; Alkan, S.; Cinar, B. STAT3 and STAT5A are potential therapeutic targets in castration-resistant prostate cancer. Oncotarget 2017, 8. [CrossRef]

17. Gu, L.; Dagvadorj, A.; Lutz, J.; Leiby, B.; Bonuccelli, G.; Lisanti, M.P.; Addya, S.; Fortina, P.; Dasgupta, A.; Hyslop, T.; et al. Transcription Factor Stat3 Stimulates Metastatic Behavior of Human Prostate Cancer Cells in Vivo, whereas Stat5b Has a Preferential Role in the Promotion of Prostate Cancer Cell Viability and Tumor Growth. Am. J. Pathol. 2010, 176, 1959-1972. [CrossRef]

18. Boutillon, F.; Pigat, N.; Sackmann Sala, L.; Reyes-Gomez, E.; Moriggl, R.; Guidotti, J.-E.; Goffin, V. STAT5a/b Deficiency Delays, but does not Prevent, Prolactin-Driven Prostate Tumorigenesis in Mice. Cancers 2019, 11, 929. [CrossRef]

19. Cahu, X.; Constantinescu, S.N. Oncogenic Drivers in Myeloproliferative Neoplasms: From JAK2 to Calreticulin Mutations. Curr. Hematol. Malig. Rep. 2015, 10, 335-343. [CrossRef]

20. Staerk, J.; Constantinescu, S.N. The JAK-STAT pathway and hematopoietic stem cells from the JAK2 V617F perspective. JAK-STAT 2012, 1, 184-190. [CrossRef]

21. Warsch, W.; Walz, C.; Sexl, V. JAK of all trades: JAK2-STAT5 as novel therapeutic targets in BCR-ABL1+ chronic myeloid leukemia. Blood 2014, 122, 2167-2175. [CrossRef] [PubMed]

22. Hoelbl, A.; Kovacic, B.; Kerenyi, M.A.; Simma, O.; Warsch, W.; Cui, Y.; Beug, H.; Hennighausen, L.; Moriggl, R.; Sexl, V. Clarifying the role of Stat5 in lymphoid development and Abelson-induced transformation. Blood 2006, 107, 4898. [CrossRef]

23. Pham, H.T.T.; Maurer, B.; Prchal-Murphy, M.; Grausenburger, R.; Grundschober, E.; Javaheri, T.; Nivarthi, H.; Boersma, A.; Kolbe, T.; Elabd, M.; et al. STAT5BN642H is a driver mutation for T cell neoplasia. J. Clin. Invest. 2018, 128, 387-401. [CrossRef] [PubMed]

24. Waldmann, T.A.; Chen, J. Disorders of the JAK/STAT Pathway in T Cell Lymphoma Pathogenesis: Implications for Immunotherapy. Annu. Rev. Immunol. 2017, 35, 533-550. [CrossRef]

25. Schrader, A.; Crispatzu, G.; Oberbeck, S.; Mayer, P.; Pützer, S.; von Jan, J.; Vasyutina, E.; Warner, K.; Weit, N.; Pflug, N.; et al. Actionable perturbations of damage responses by TCL1/ATM and epigenetic lesions form the basis of T-PLL. Nat. Commun. 2018, 9, 697. [CrossRef]

26. Koppikar, P.; Bhagwat, N.; Kilpivaara, O.; Manshouri, T.; Adli, M.; Hricik, T.; Liu, F.; Saunders, L.M.; Mullally, A.; Abdel-Wahab, O.; et al. Heterodimeric JAK-STAT activation as a mechanism of persistence to JAK2 inhibitor therapy. Nature 2012, 489, 155-159. [CrossRef]

27. Berger, A.; Sexl, V.; Valent, P.; Moriggl, R. Inhibition of STAT5: a therapeutic option in BCR-ABL1-driven leukemia. Oncotarget 2014, 5, 9564-9576. [CrossRef]

28. Cumaraswamy, A.A.; Lewis, A.M.; Geletu, M.; Todic, A.; Diaz, D.B.; Cheng, X.R.; Brown, C.E.; Laister, R.C.; Muench, D.; Kerman, K.; et al. Nanomolar-Potency Small Molecule Inhibitor of STAT5 Protein. ACS Med. Chem. Lett. 2014, 5, 1202-1206. [CrossRef]

29. Mertens, C.; Zhong, M.; Krishnaraj, R.; Zou, W.; Chen, X.; Darnell, J.E. Dephosphorylation of phosphotyrosine on STAT1 dimers requires extensive spatial reorientation of the monomers facilitated by the N-terminal domain. Genes Dev. 2006, 20, 3372-3381.

30. Neculai, D.; Neculai, A.M.; Verrier, S.; Straub, K.; Klumpp, K.; Pfitzner, E.; Becker, S. Structure of the Unphosphorylated STAT5a Dimer. J. Biol. Chem. 2005, 280, 40782-40787. [CrossRef]

31. Fahrenkamp, D.; Li, J.; Ernst, S.; Schmitz-Van de Leur, H.; Chatain, N.; Küster, A.; Koschmieder, S.; Lüscher, B.; Rossetti, G.; Müller-Newen, G. Intramolecular hydrophobic interactions are critical mediators of STAT5 dimerization. Sci. Rep. 2016, 6, 35454. [CrossRef] [PubMed]

32. Moriggl, R.; Sexl, V.; Kenner, L.; Duntsch, C.; Stangl, K.; Gingras, S.; Hoffmeyer, A.; Bauer, A.; Piekorz, R.; Wang, D.; et al. Stat5 tetramer formation is associated with leukemogenesis. Cancer Cell 2005, 7, 87-99. [CrossRef]

33. Lin, J.-X.; Du, N.; Li, P.; Kazemian, M.; Gebregiorgis, T.; Spolski, R.; Leonard, W.J. Critical functions for STAT5 tetramers in the maturation and survival of natural killer cells. Nat. Commun. 2017, 8, 1320. [CrossRef] 
34. de Araujo, E.D.; Erdogan, F.; Neubauer, H.A.; Meneksedag-Erol, D.; Manaswiyoungkul, P.; Eram, M.S.; Seo, H.-S.; Qadree, A.K.; Israelian, J.; Orlova, A.; et al. Structural and functional consequences of the STAT5BN642H driver mutation. Nat. Commun. 2019, 10, 2517. [CrossRef] [PubMed]

35. Park, H.J.; Li, J.; Hannah, R.; Biddie, S.; Leal-Cervantes, A.I.; Kirschner, K.; Flores Santa Cruz, D.; Sexl, V.; Go ttgens, B.; Green, A.R. Cytokine-induced megakaryocytic differentiation is regulated by genome-wide loss of a uSTAT transcriptional program. EMBO J. 2016, 35, 580-594. [CrossRef] [PubMed]

36. Zhao, Y.; Zeng, C.; Tarasova, N.I.; Chasovskikh, S.; Dritschilo, A.; Timofeeva, O.A. A new role for STAT3 as a regulator of chromatin topology. Transcription 2013, 4, 227-231. [CrossRef]

37. Kornfeld, J.-W.; Grebien, F.; Kerenyi, M.A.; Friedbichler, K.; Kovacic, B.; Zankl, B.; Hoelbl, A.; Nivarti, H.; Beug, H.; Sexl, V.; et al. The different functions of Stat 5 and chromatin alteration through Stat5 proteins. Front. Biosci. J. Virtual Libr. 2008, 13, 6237-6254. [CrossRef]

38. Li, G.; Wang, Z.; Zhang, Y.; Kang, Z.; Haviernikova, E.; Cui, Y.; Hennighausen, L.; Moriggl, R.; Wang, D.; Tse, W.; et al. STAT5 requires the N-domain to maintain hematopoietic stem cell repopulating function and appropriate lymphoid-myeloid lineage output. Exp. Hematol. 2007, 35, 1684-1694. [CrossRef]

39. Murphy, T.; Yee, K.W.L. Cytarabine and daunorubicin for the treatment of acute myeloid leukemia. Expert Opin. Pharmacother. 2017, 18, 1765-1780. [CrossRef]

40. Ota, N.; Brett, T.J.; Murphy, T.L.; Fremont, D.H.; Murphy, K.M. N-domain-dependent nonphosphorylated STAT4 dimers required for cytokine-driven activation. Nat. Immunol. 2004, 5, 208-215. [CrossRef]

41. Vogt, M.; Domoszlai, T.; Kleshchanok, D.; Lehmann, S.; Schmitt, A.; Poli, V.; Richtering, W.; Muller-Newen, G. The role of the N-terminal domain in dimerization and nucleocytoplasmic shuttling of latent STAT3. J. Cell Sci. 2011, 124, 900-909. [CrossRef] [PubMed]

42. Zhang, X.; Darnell, J.E. Functional Importance of Stat3 Tetramerization in Activation of the $\alpha 2$-Macroglobulin Gene. J. Biol. Chem. 2001, 276, 33576-33581. [CrossRef]

43. Hu, T.; Yeh, J.E.; Pinello, L.; Jacob, J.; Chakravarthy, S.; Yuan, G.-C.; Chopra, R.; Frank, D.A. Impact of the N-Terminal Domain of STAT3 in STAT3-Dependent Transcriptional Activity. Mol. Cell. Biol. 2015, 35, 3284. [CrossRef]

44. Yang, J.; Chatterjee-Kishore, M.; Staugaitis, S.M.; Nguyen, H.; Schlessinger, K.; Levy, D.E.; Stark, G.R. Novel Roles of Unphosphorylated STAT3 in Oncogenesis and Transcriptional Regulation. Cancer Res. 2005, 65, 939. [PubMed]

45. Pfeffer, S.R.; Fan, M.; Du, Z.; Yang, C.H.; Pfeffer, L.M. Unphosphorylated STAT3 regulates the antiproliferative, antiviral, and gene-inducing actions of type I interferons. Biochem. Biophys. Res. Commun. 2017, 490, 739-745. [CrossRef]

46. Yang, J.; Liao, X.; Agarwal, M.K.; Barnes, L.; Auron, P.E.; Stark, G.R. Unphosphorylated STAT3 accumulates in response to IL-6 and activates transcription by binding to NFKB. Genes Dev. 2007, 21, 1396-1408.

47. Timofeeva, O.A.; Tarasova, N.I.; Zhang, X.; Chasovskikh, S.; Cheema, A.K.; Wang, H.; Brown, M.L.; Dritschilo, A. STAT3 suppresses transcription of proapoptotic genes in cancer cells with the involvement of its N-terminal domain. Proc. Natl. Acad. Sci. USA 2013, 110, 1267-1272. [CrossRef]

48. Lee, J.E.; Yang, Y.-M.; Liang, F.-X.; Gough, D.J.; Levy, D.E.; Sehgal, P.B. Nongenomic STAT5-dependent effects on Golgi apparatus and endoplasmic reticulum structure and function. Am. J. Physiol. Cell Physiol. 2011, 302, C804-C820. [CrossRef]

49. Hu, X.; Dutta, P.; Tsurumi, A.; Li, J.; Wang, J.; Land, H.; Li, W.X. Unphosphorylated STAT5A stabilizes heterochromatin and suppresses tumor growth. Proc. Natl. Acad. Sci. USA 2013, 110, 10213-10218. [CrossRef]

50. Engblom, D.; Kornfeld, J.-W.; Schwake, L.; Tronche, F.; Reimann, A.; Beug, H.; Hennighausen, L.; Moriggl, R.; Schutz, G. Direct glucocorticoid receptor-Stat5 interaction in hepatocytes controls body size and maturation-related gene expression. Genes Dev. 2007, 21, 1157-1162.

51. Freund, P.; Kerenyi, M.A.; Hager, M.; Wagner, T.; Wingelhofer, B.; Pham, H.T.T.; Elabd, M.; Han, X.; Valent, P.; Gouilleux, F.; et al. O-GlcNAcylation of STAT5 controls tyrosine phosphorylation and oncogenic transcription in STAT5-dependent malignancies. Leukemia 2017, 31, 2132-2142. [CrossRef]

52. Lin, J.-X.; Li, P.; Liu, D.; Jin, H.T.; He, J.; Rasheed, M.A.U.; Rochman, Y.; Wang, L.; Cui, K.; Liu, C.; et al. Critical Role of STAT5 Transcription Factor Tetramerization for Cytokine Responses and Normal Immune Function. Immunity 2012, 36, 586-599. [CrossRef] 
53. Rauth, M.; Freund, P.; Orlova, A.; Grünert, S.; Tasic, N.; Han, X.; Ruan, H.-B.; Neubauer, A.H.; Moriggl, R. Cell Metabolism Control Through O-GlcNAcylation of STAT5: A Full or Empty Fuel Tank Makes a Big Difference for Cancer Cell Growth and Survival. Int. J. Mol. Sci. 2019, 20, 1028. [CrossRef] [PubMed]

54. Litterst, C.M.; Kliem, S.; Marilley, D.; Pfitzner, E. NCoA-1/SRC-1 Is an Essential Coactivator of STAT5 That Binds to the FDL Motif in the $\alpha$-Helical Region of the STAT5 Transactivation Domain. J. Biol. Chem. 2003, 278, 45340-45351. [CrossRef]

55. Nanou, A.; Toumpeki, C.; Lavigne, M.D.; Lazou, V.; Demmers, J.; Paparountas, T.; Thanos, D.; Katsantoni, E. The dual role of LSD1 and HDAC3 in STAT5-dependent transcription is determined by protein interactions, binding affinities, motifs and genomic positions. Nucleic Acids Res. 2016, 45, 142-154. [CrossRef]

56. Yang, R.; Qu, C.; Zhou, Y.; Konkel, J.E.; Shi, S.; Liu, Y.; Chen, C.; Liu, S.; Liu, D.; Chen, Y.; et al. Hydrogen Sulfide Promotes Tet1- and Tet2-Mediated Foxp3 Demethylation to Drive Regulatory T Cell Differentiation and Maintain Immune Homeostasis. Immunity 2015, 43, 251-263. [CrossRef]

57. Zhang, Q.; Wang, H.Y.; Marzec, M.; Raghunath, P.N.; Nagasawa, T.; Wasik, M.A. STAT3- and DNA methyltransferase 1-mediated epigenetic silencing of SHP-1 tyrosine phosphatase tumor suppressor gene in malignant T lymphocytes. Proc. Natl. Acad. Sci. USA 2005, 102, 6948. [CrossRef]

58. Wang, R.; Cherukuri, P.; Luo, J. Activation of Stat3 Sequence-specific DNA Binding and Transcription by p300/CREB-binding Protein-mediated Acetylation. J. Biol. Chem. 2005, 280, 11528-11534. [CrossRef]

59. Yang, J.; Huang, J.; Dasgupta, M.; Sears, N.; Miyagi, M.; Wang, B.; Chance, M.R.; Chen, X.; Du, Y.; Wang, Y.; et al. Reversible methylation of promoter-bound STAT3 by histone-modifying enzymes. Proc. Natl. Acad. Sci. USA 2010, 107, 21499. [CrossRef]

60. Dasgupta, M.; Dermawan, J.K.T.; Willard, B.; Stark, G.R. STAT3-driven transcription depends upon the dimethylation of K49 by EZH2. Proc. Natl. Acad. Sci. USA 2015, 112, 3985. [CrossRef]

61. Hossain, D.M.S.; Panda, A.K.; Manna, A.; Mohanty, S.; Bhattacharjee, P.; Bhattacharyya, S.; Saha, T.; Chakraborty, S.; Kar, R.K.; Das, T.; et al. FoxP3 acts as a cotranscription factor with STAT3 in tumor-induced regulatory T cells. Immunity 2013, 39, 1057-1069. [CrossRef] [PubMed]

62. Mandal, M.; Powers, S.E.; Maienschein-Cline, M.; Bartom, E.T.; Hamel, K.M.; Kee, B.L.; Dinner, A.R.; Clark, M.R. Epigenetic repression of the Igk locus by STAT5-mediated recruitment of the histone methyltransferase Ezh2. Nature Immunol. 2011, 12, 1212-1220. [CrossRef] [PubMed]

63. Boumahdi, S.; de Sauvage, F.J. The great escape: tumour cell plasticity in resistance to targeted therapy. Nat. Rev. Drug Discov. 2019. [CrossRef] [PubMed]

64. Schust, J.; Sperl, B.; Hollis, A.; Mayer, T.U.; Berg, T. Stattic: A Small-Molecule Inhibitor of STAT3 Activation and Dimerization. Chem. Biol. 2006, 13, 1235-1242.

65. Becker, S.; Groner, B.; Müller, C.W. Three-dimensional structure of the Stat $3 \beta$ homodimer bound to DNA. Nature 1998, 394, 145-151. [CrossRef]

66. Song, H.; Wang, R.; Wang, S.; Lin, J. A low-molecular-weight compound discovered through virtual database screening inhibits Stat3 function in breast cancer cells. Proc. Natl. Acad. Sci. USA 2005, 102, 4700. [CrossRef]

67. Lin, L.; Hutzen, B.; Li, P.-K.; Ball, S.; Zuo, M.; DeAngelis, S.; Foust, E.; Sobo, M.; Friedman, L.; Bhasin, D.; et al. A novel small molecule, LLL12, inhibits STAT3 phosphorylation and activities and exhibits potent growth-suppressive activity in human cancer cells. Neoplasia 2010, 12, 39-50. [CrossRef]

68. Fuh, B.; Sobo, M.; Cen, L.; Josiah, D.; Hutzen, B.; Cisek, K.; Bhasin, D.; Regan, N.; Lin, L.; Chan, C.; et al. LLL-3 inhibits STAT3 activity, suppresses glioblastoma cell growth and prolongs survival in a mouse glioblastoma model. Br. J. Cancer 2009, 100, 106-112. [CrossRef]

69. Fletcher, S.; Singh, J.; Zhang, X.; Yue, P.; Page, B.D.G.; Sharmeen, S.; Shahani, V.M.; Zhao, W.; Schimmer, A.D.; Turkson, J.; et al. Disruption of transcriptionally active Stat3 dimers with non-phosphorylated, salicylic acid-based small molecules: potent in vitro and tumor cell activities. Chembiochem Eur. J. Chem. Biol. 2009, 10, 1959-1964. [CrossRef]

70. Urlam, M.K.; Pireddu, R.; Ge, Y.; Zhang, X.; Sun, Y.; Lawrence, H.R.; Guida, W.C.; Sebti, S.M.; Lawrence, N.J. Development of new N-Arylbenzamides as STAT3 Dimerization Inhibitors. MedChemComm 2013, 4, 932-941. [CrossRef]

71. Siddiquee, K.; Zhang, S.; Guida, W.C.; Blaskovich, M.A.; Greedy, B.; Lawrence, H.R.; Yip, M.L.R.; Jove, R.; McLaughlin, M.M.; Lawrence, N.J.; et al. Selective chemical probe inhibitor of Stat3, identified through structure-based virtual screening, induces antitumor activity. Proc. Natl. Acad. Sci. USA 2007, 104, 7391. [CrossRef] [PubMed] 
72. Xu, X.; Kasembeli, M.M.; Jiang, X.; Tweardy, B.J.; Tweardy, D.J. Chemical Probes that Competitively and Selectively Inhibit Stat3 Activation. PLoS ONE 2009, 4, e4783. [CrossRef] [PubMed]

73. Matsuno, K.; Masuda, Y.; Uehara, Y.; Sato, H.; Muroya, A.; Takahashi, O.; Yokotagawa, T.; Furuya, T.; Okawara, T.; Otsuka, M.; et al. Identification of a New Series of STAT3 Inhibitors by Virtual Screening. ACS Med. Chem. Lett. 2010, 1, 371-375. [CrossRef] [PubMed]

74. Shin, D.-S.; Kim, H.-N.; Shin, K.D.; Yoon, Y.J.; Kim, S.-J.; Han, D.C.; Kwon, B.-M. Cryptotanshinone Inhibits Constitutive Signal Transducer and Activator of Transcription 3 Function through Blocking the Dimerization in DU145 Prostate Cancer Cells. Cancer Res. 2008, 69. [CrossRef] [PubMed]

75. Lin, L.; Hutzen, B.; Ball, S.; Foust, E.; Sobo, M.; Deangelis, S.; Pandit, B.; Friedman, L.; Li, C.; Li, P.-K.; et al. New curcumin analogues exhibit enhanced growth-suppressive activity and inhibit AKT and signal transducer and activator of transcription 3 phosphorylation in breast and prostate cancer cells. Cancer Sci. 2009, 100, 1719-1727. [CrossRef]

76. Amani, H.; Ajami, M.; Nasseri Maleki, S.; Pazoki-Toroudi, H.; Daglia, M.; Tsetegho Sokeng, A.J.; Di Lorenzo, A.; Nabavi, S.F.; Devi, K.P.; Nabavi, S.M. Targeting signal transducers and activators of transcription (STAT) in human cancer by dietary polyphenolic antioxidants. Biochimie 2017, 142, 63-79. [CrossRef]

77. Li, M.; Yue, G.G.-L.; Song, L.-H.; Huang, M.-B.; Lee, J.K.-M.; Tsui, S.K.-W.; Fung, K.-P.; Tan, N.-H.; Lau, C.B.-S. Natural small molecule bigelovin suppresses orthotopic colorectal tumor growth and inhibits colorectal cancer metastasis via IL6/STAT3 pathway. Biochem. Pharmacol. 2018, 150, 191-201. [CrossRef]

78. Verdura, S.; Cuyàs, E.; Llorach-Parés, L.; Pérez-Sánchez, A.; Micol, V.; Nonell-Canals, A.; Joven, J.; Valiente, M.; Sánchez-Martínez, M.; Bosch-Barrera, J.; et al. Silibinin is a direct inhibitor of STAT3. Food Chem. Toxicol. 2018, 116, 161-172. [CrossRef]

79. Yu, W.; Xiao, H.; Lin, J.; Li, C. Discovery of Novel STAT3 Small Molecule Inhibitors via in Silico Site-Directed Fragment-Based Drug Design. J. Med. Chem. 2013, 56, 4402-4412. [CrossRef]

80. Zhang, M.; Zhu, W.; Li, Y. Discovery of novel inhibitors of signal transducer and activator of transcription 3 (STAT3) signaling pathway by virtual screening. Eur. J. Med. Chem. 2013, 62, 301-310. [CrossRef]

81. Leung, K.; Liu, L.; Lin, S.; Lu, L.; Zhong, H.; Susanti, D.; Rao, W.; Wang, M.; Ian, W.; Chan, D.S.; et al. Discovery of a small-molecule inhibitor of STAT3 by ligand-based pharmacophore screening. Methods 2015, 71, 38-43. [CrossRef]

82. Tolcher, A.; Flaherty, K.; Shapiro, G.I.; Berlin, J.; Witzig, T.; Habermann, T.; Bullock, A.; Rock, E.; Elekes, A.; Lin, C.; et al. A First-in-Human Phase I Study of OPB-111077, a Small-Molecule STAT3 and Oxidative Phosphorylation Inhibitor, in Patients with Advanced Cancers. Oncologist 2018, 23, 658-e72. [CrossRef] [PubMed]

83. Yoo, C.; Kang, J.; Lim, H.Y.; Kim, J.H.; Lee, M.-A.; Lee, K.-H.; Kim, T.-Y.; Ryoo, B.-Y. Phase I Dose-Finding Study of OPB-111077, a Novel STAT3 Inhibitor, in Patients with Advanced Hepatocellular Carcinoma. Cancer Res. Treat. 2018, 51, 510-518. [CrossRef] [PubMed]

84. Li, C.; Xu, L.; Jian, L.; Yu, R.; Zhao, J.; Sun, L.; Du, G.; Liu, X. Stattic inhibits RANKL-mediated osteoclastogenesis by suppressing activation of STAT3 and NF- KB pathways. Int. Immunopharmacol. 2018, 58, 136-144. [CrossRef] [PubMed]

85. Adachi, M.; Cui, C.; Dodge, C.T.; Bhayani, M.K.; Lai, S.Y. Targeting STAT3 inhibits growth and enhances radiosensitivity in head and neck squamous cell carcinoma. Oral Oncol. 2012, 48, 1220-1226. [CrossRef]

86. Miyoshi, K.; Takaishi, M.; Nakajima, K.; Ikeda, M.; Kanda, T.; Tarutani, M.; Iiyama, T.; Asao, N.; DiGiovanni, J.; Sano, S. Stat3 as a Therapeutic Target for the Treatment of Psoriasis: A Clinical Feasibility Study with STA-21, a Stat3 Inhibitor. J. Investig. Dermatol. 2011, 131, 108-117. [CrossRef]

87. Nie, Y.; Li, Y.; Hu, S. A novel small inhibitor, LLL12, targets STAT3 in non-small cell lung cancer in vitro and in vivo. Oncol. Lett. 2018, 16, 5349-5354. [CrossRef]

88. Zhang, X.; Sun, Y.; Pireddu, R.; Yang, H.; Urlam, M.K.; Lawrence, H.R.; Guida, W.C.; Lawrence, N.J.; Sebti, S.M. A novel inhibitor of STAT3 homodimerization selectively suppresses STAT3 activity and malignant transformation. Cancer Res. 2013, 73, 1922-1933. [CrossRef]

89. Xiao, H.; Bid, H.K.; Jou, D.; Wu, X.; Yu, W.; Li, C.; Houghton, P.J.; Lin, J. A Novel Small Molecular STAT3 Inhibitor, LY5, Inhibits Cell Viability, Cell Migration, and Angiogenesis in Medulloblastoma Cells. J. Biol. Chem. 2015, 290, 3418-3429. [CrossRef]

90. Müller, J.; Schust, J.; Berg, T. A high-throughput assay for signal transducer and activator of transcription $5 \mathrm{~b}$ based on fluorescence polarization. Anal. Biochem. 2008, 375, 249-254. 
91. Müller, J.; Sperl, B.; Reindl, W.; Kiessling, A.; Berg, T. Discovery of Chromone-Based Inhibitors of the Transcription Factor STAT5. ChemBioChem 2008, 9, 723-727. [CrossRef] [PubMed]

92. Page, B.D.G.; Khoury, H.; Laister, R.C.; Fletcher, S.; Vellozo, M.; Manzoli, A.; Yue, P.; Turkson, J.; Minden, M.D.; Gunning, P.T. Small Molecule STAT5-SH2 Domain Inhibitors Exhibit Potent Antileukemia Activity. J. Med. Chem. 2012, 55, 1047-1055. [CrossRef] [PubMed]

93. de Araujo, E.D.; Manaswiyoungkul, P.; Israelian, J.; Park, J.; Yuen, K.; Farhangi, S.; Berger-Becvar, A.; Abu-Jazar, L.; Gunning, P.T. High-throughput thermofluor-based assays for inhibitor screening of STAT SH2 domains. J. Pharm. Biomed. Anal. 2017, 143, 159-167. [CrossRef] [PubMed]

94. de Araujo, E.D.; Manaswiyoungkul, P.; Erdogan, F.; Qadree, A.K.; Sina, D.; Tin, G.; Toutah, K.; Yuen, K.; Gunning, P.T. A functional in vitro assay for screening inhibitors of STAT5B phosphorylation. J. Pharm. Biomed. Anal. 2019, 162, 60-65. [CrossRef]

95. Wingelhofer, B.; Maurer, B.; Heyes, E.C.; Cumaraswamy, A.C.; Berger-Becvar, A.; de Araujo, E.D.; Orlova, A.; Freund, P.; Ruge, F.; Park, J.; et al. Pharmacologic inhibition of STAT5 in acute myeloid leukemia. Leukemia 2018, 32, 1135-1146. [CrossRef]

96. Nelson, E.A.; Walker, S.R.; Weisberg, E.; Bar-natan, M.; Barrett, R.; Gashin, L.B.; Terrell, S.; Klitgaard, J.L.; Santo, L.; Addorio, M.R.; et al. The STAT5 inhibitor pimozide decreases survival of chronic myelogenous leukemia cells resistant to kinase inhibitors. Blood 2017, 117, 3421-3430. [CrossRef]

97. Rondanin, R.; Simoni, D.; Romagnoli, R.; Baruchello, R.; Marchetti, P.; Costantini, C.; Fochi, S.; Padroni, G.; Grimaudo, S.; Maria, R.; et al. Inhibition of activated STAT5 in Bcr/Abl expressing leukemia cells with new pimozide derivatives. Bioorg. Med. Chem. Lett. 2014, 24, 4568-4574.

98. Romagnoli, R.; Baraldi, P.G.; Prencipe, F.; Lopez-Cara, C.; Rondanin, R.; Simoni, D.; Hamel, E.; Grimaudo, S.; Pipitone, R.M.; Meli, M.; et al. Novel iodoacetamido benzoheterocyclic derivatives with potent antileukemic activity are inhibitors of STAT5 phosphorylation. Eur. J. Med. Chem. 2016, 108, 39-52. [CrossRef]

99. Liao, Z.; Gu, L.; Vergalli, J.; Mariani, S.A.; De Dominici, M.; Lokareddy, R.K.; Dagvadorj, A.; Purushottamachar, P.; McCue, P.A.; Trabulsi, E.; et al. Structure-based screen identifies a potent small-molecule inhibitor of Stat5a/b with therapeutic potential for prostate cancer and chronic myeloid leukemia. Mol. Cancer Ther. 2015, 14, 1777-1794. [CrossRef]

100. Elumalai, N.; Berg, A.; Natarajan, K.; Scharow, A.; Berg, T. Nanomolar Inhibitors of the Transcription Factor STAT5b with High Selectivity over STAT5a. Angew. Chem. Int. Ed. 2015, 54, 4758-4763. [CrossRef]

101. Elumalai, N.; Berg, A.; Rubner, S.; Blechschmidt, L.; Song, C.; Natarajan, K.; Matysik, J.; Berg, T. Rational development of Stafib-2: a selective, nanomolar inhibitor of the transcription factor STAT5b. Sci. Rep. 2017, 7, 819. [CrossRef] [PubMed]

102. Natarajan, K.; Müller-Klieser, D.; Rubner, S.; Berg, T. Stafia-1: a STAT5a-selective inhibitor developed via docking-based screening of in silico O-phosphorylated fragments. Chem. Eur. J. 2019, in press. [CrossRef] [PubMed]

103. Juen, L.; Brachet-Botineau, M.; Parmenon, C.; Bourgeais, J.; Hérault, O.; Gouilleux, F.; Viaud-Massuard, M.-C.; Prié, G. New Inhibitor Targeting Signal Transducer and Activator of Transcription 5 (STAT5) Signaling in Myeloid Leukemias. J. Med. Chem. 2017, 60, 6119-6136. [CrossRef]

104. Berg, A.; Sperl, B.; Berg, T. ATP Inhibits the Transcription Factor STAT5b. ChemBioChem 2019, 20, $2227-2231$. [CrossRef]

105. Wong, E.L.; Nawrotzky, E.; Arkona, C.; Kim, B.G.; Beligny, S.; Wang, X.; Wagner, S.; Lisurek, M.; Carstanjen, D.; Rademann, J. The transcription factor STAT5 catalyzes Mannich ligation reactions yielding inhibitors of leukemic cell proliferation. Nat. Commun. 2019, 10, 66. [CrossRef]

106. Parmenon, C.; Guillard, J.; Caignard, D.-H.; Hennuyer, N.; Staels, B.; Audinot-Bouchez, V.; Boutin, J.-A.; Dacquet, C.; Ktorza, A.; Viaud-Massuard, M.-C. 4,4-Dimethyl-1,2,3,4-tetrahydroquinoline-based PPAR $\alpha / \gamma$ agonists. Part I: Synthesis and pharmacological evaluation. Bioorg. Med. Chem. Lett. 2008, $18,1617-1622$.

(C) 2019 by the authors. Licensee MDPI, Basel, Switzerland. This article is an open access article distributed under the terms and conditions of the Creative Commons Attribution (CC BY) license (http://creativecommons.org/licenses/by/4.0/). 